\title{
Extraction of Mangiferin and Chemical Characterization and Sensorial Analysis of Teas from Mangifera indica L. Leaves of the Ubá Variety
}

\author{
Natalia Medina Ramírez ${ }^{1, *}$, Leticia Monteiro Farias ${ }^{2}$, Francine Apolonio Santana ${ }^{1}$, \\ João Paulo Viana Leite ${ }^{2}$, Maria Inês De Souza Dantas ${ }^{1}$, Renata Celi Lopes Toledo ${ }^{1}$, \\ José Humberto De Queiroz ${ }^{2}$, Hércia Stampini Duarte Martino ${ }^{1}$ \\ and Sônia Machado Rocha Ribeiro ${ }^{1}$ \\ 1 Department of Nutrition and Health, Federal University of Viçosa, Av. PH Rolfs, s/n, \\ 36570-000 Viçosa, Minas Gerais, Brazil; francine.santana@ufv.br (F.A.S.); msdantas@ufv.br (M.I.D.S.D.); \\ renata.lopestoledo@ufv.br (R.C.L.T.); hercia@ufv.br (H.S.D.M.); somarori@gmail.com (S.M.R.R.) \\ 2 Department of Biochemistry and Molecular Biology, Federal University of Viçosa, Av. PH Rolfs, s/n, \\ 36570-000 Viçosa, Minas Gerais, Brazil; leticia.farias@ufv.br (L.M.F.); jpvleite@ufv.br (J.P.V.L.); \\ jqueiroz@ufv.br (J.H.D.Q.) \\ * Correspondence: natalia.ramirez@ufv.br; Tel.: +55-31-9947-95430; Fax: +55-31-3899-1276
}

Academic Editor: Quan V. Vuong

Received: 30 May 2016; Accepted: 12 November 2016; Published: 23 November 2016

\begin{abstract}
Mangiferin is present in various parts of Mangifera indica L. and has proven biological activities, such as antioxidant capabilities. The aim of this work was to evaluate the chemical composition of teas prepared from $M$. indica leaves, their potential use as a source of mangiferin and their total phenolic compounds. Teas were prepared with young and mature leaves of $M$. indica at three (medicinal plant: solvent) ratios utilizing three different preparation techniques. The mangiferin content was analyzed via high-performance liquid chromatography (HPLC). The tea with the highest mangiferin content was characterized for its total phenolic content and antioxidant activity. The oxidative stability was also evaluated by quantifying mangiferin, total phenolics and antioxidant activity using two preservation treatments for 0,24 and $48 \mathrm{~h}$. Sensory analysis was performed to measure the acceptance of the tea. The type of leaf, preparation technique and concentration influenced the mangiferin content in the teas. The highest concentration of mangiferin was obtained through decoction at a $5 \%(\mathrm{w} / \mathrm{v})$ medicinal plant concentration. This tea exhibited stability up to $48 \mathrm{~h}$ after preparation under both preservation treatments and provided a positive sensory acceptance for consumers with flavors added. In conclusion, teas made from $M$. indica leaves have great potential as sources of mangiferin and phenolic compounds.
\end{abstract}

Keywords: acceptance; antioxidant activity; leaf tea; mangiferin; mango; stability

\section{Introduction}

Tea is among the most consumed natural beverages worldwide due to its great benefits $[1,2]$. Chinese medicine, for instance, suggests the ingestion of plant parts in the form of tea for different purposes, such as energy improvement and sedative, stimulant, antihypertensive, stomachic and detoxifying actions, as well as depression treatment and the promotion of longevity [3-5]. In traditional medicine, mango leaf tea is popularly used for therapeutic purposes to treat influenza, diarrhea and throat disorders [6]. Thus, tea is a beverage choice with the potential to be consumed as a coadjuvant in the treatment or prevention of chronic non-communicable diseases [7].

In Brazil, statistics show that in recent years, the consumption of teas prepared from medicinal plants has increased by $16 \%$ [8]. The growing consumer interest in teas is mainly due to their 
functional properties, as most of them are sources of bioactive compounds and a myriad of substances with potential benefits for human health. These bioactive compounds include simple phenols and polyphenols, flavonoids, anthocyanins, tannins and others [3,9-11].

Mangifera indica leaves contain phenolic secondary metabolites, including gallic acid, quercetin $3-\beta$-D glucoside, $\alpha$ tocopherol, 3-methyl-gallate, propyl gallate, propyl benzoate $(+)$ catechin, $(-)$ epicatechin, benzoic acid and D-glucose [12,13]. Mangiferin (1,3,6,7-tetrahydroxy-2-[(2S,3R,4R,5S,6R)3,4,5-trihydroxy-6-(hydroxymethyl)oxan-2-yl]xanthen-9-one), of the xanthone group (Figure 1), is a major constituent of the leaves and stem bark of Mangifera indica L. (Anacardiaceae) and has antioxidant, immunomodulatory and anti-inflammatory activities [14]. For example, Cuba has a product commercialized as a nutritional supplement named VIMANG ${ }^{\circledR}$, whose major component is mangiferin [15]. Due to its biological effects as an antioxidant and anti-inflammatory agent, it is interesting to consider the development of beverages containing mangiferin to incorporate its functional properties into the diet of individuals with chronic, non-communicable diseases that manifest subclinical inflammation and oxidative stress [16,17].

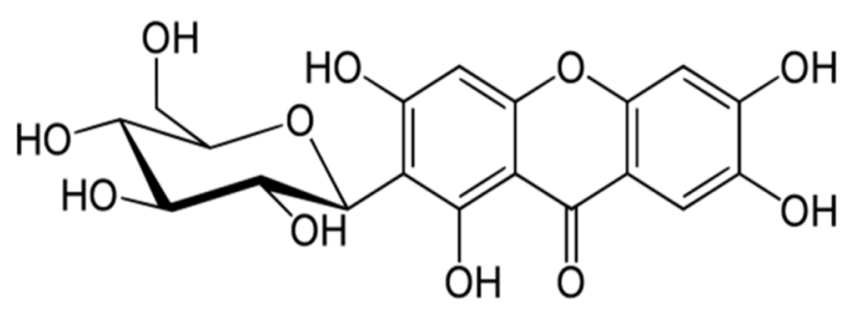

Figure 1. Chemical structure of mangiferin.

Brazilian sanitary legislation considers teas to be traditional herbal products, which are defined as "plant drugs with medicinal purposes that are prepared by infusion, decoction or maceration with water" [18]. This legislation currently allows M. indica extracts to be utilized for the development of beverages enriched with bioactive compounds. Because consumer opinion is important in this scenario, sensory testing is fundamental to gathering knowledge for the launch of appealing beverages with a high level of acceptance. Blind tests and expectation tests are widely used for this purpose [19-21].

Research on the use of herbal beverages and medicinal plants has been gaining importance due to their therapeutic and healing properties, low price and availability [22-25]. This is a positive development, considering the vast biodiversity of plants in Brazil and the need for deeper knowledge concerning the potential use of teas as adjuvants in the control and treatment of chronic non-communicable diseases.

This work aimed to evaluate $M$. indica leaf tea as a source of mangiferin and total phenolics. The teas were prepared by three techniques at three different concentrations of the medicinal plant. The tea with the highest mangiferin content was chosen for analysis of its antioxidant activity stability and consumer acceptance. The results provide data for future studies with an emphasis on the development of new beverages with health claims and the evaluation of their functional effects.

\section{Materials and Methods}

\subsection{Chemicals}

Folin-Ciocalteu reagent, 2,2-diphenyl-1-picrylhydrazyl (DPPH), absolute ethanol $\left(\mathrm{CH}_{3} \mathrm{CH}_{2} \mathrm{OH}\right)$ and mangiferin were acquired from Sigma-Aldrich (Saint Louis, MO, USA). Acetic acid P.A. and acetonitrile of HPLC grade were purchased from Merck (São Paulo, Brazil). The other reagents were of analytical grade. 


\subsection{Plant}

Mature leaves (dark green, located far from the branch tips) and young leaves (light green, located at the branch apex) were collected from different $M$. indica trees (Ubá variety) in the Zona da Mata region, southeast of Minas Gerais State, Brazil. ( $20^{\circ} 60^{\prime} \mathrm{S}, 43^{\circ} 06^{\prime} \mathrm{W}, 183 \mathrm{~m}$ ). The specimens were identified, and an authentication certificate (No. VIC37611) was issued by the botanical survey of the Federal University of Viçosa herbarium. The leaves were washed and sanitized with chlorine solution (200 $\mathrm{mg} \cdot \mathrm{mL}^{-1}$ ) and then dried at $55 \pm 2{ }^{\circ} \mathrm{C}$ for $38 \mathrm{~h}$ in an oven with air circulation (Marconi MA035, Piracicaba, SP, Brazil). The samples were crushed (Marconi Rotor Mill MA090/CFT, Piracicaba, SP, Brazil) to obtain a fine powder, and the resulting "medicinal plant" was packaged in polypropylene bags (Selovac 200B, São Paulo, SP, Brazil).

\subsection{Tea Development through Different Methods of Preparation}

\subsubsection{Preparation of Teas}

Eighteen teas were prepared using two types of leaves, three preparation techniques and three (medicinal plant: solvent) ratios (Table 1). The techniques were decoction (boiling for $5 \mathrm{~min}$ at $100{ }^{\circ} \mathrm{C}$ using direct flame), infusion (letting stand for $5 \mathrm{~min}$ in boiling water) and ultrasound (sonication at $26^{\circ} \mathrm{C}$, for $15 \mathrm{~min}$ ) using UNIQUE ${ }^{\circledR}$ ultrasonic equipment (model USC1600A). The sonication conditions were as follows: $135 \mathrm{~W}$ ultrasonic power, $40 \mathrm{kHz}$ excitation frequency and $3.8 \mathrm{~L}(300 \times 151 \times 100 \mathrm{~mm})$ in the water bath. To establish the concentration range of the medicinal plant utilized in this study, individual portions of teas available in the Brazilian market were considered $\left(2.5 \mathrm{~g} \cdot 100 \mathrm{~mL}^{-1}\right)$. The samples were filtered (Melitta paper filter $\mathrm{N}^{\circ} 4$ ), vacuum packaged (Tecnal pump, TE-058 model) and stored in sealed amber glass bottles.

Table 1. Preparation methods of the teas from Mangifera indica leaves.

\begin{tabular}{|c|c|c|}
\hline Leaf Type & Preparation Techniques & $\begin{array}{c}\text { Medicinal Plant:Solvent Ratio } \\
\text { (g of } M \text {. indica Leaves } \cdot \mathrm{mL}^{-1} \text { of Water) }\end{array}$ \\
\hline \multirow{9}{*}{ Young } & \multirow{3}{*}{ Decoction } & 0.0125 \\
\hline & & 0.0250 \\
\hline & & 0.0500 \\
\hline & \multirow{3}{*}{ Infusion } & 0.0125 \\
\hline & & 0.0250 \\
\hline & & 0.0500 \\
\hline & \multirow{3}{*}{ Ultrasound } & 0.0125 \\
\hline & & 0.0250 \\
\hline & & 0.0500 \\
\hline \multirow{9}{*}{ Mature } & \multirow{3}{*}{ Decoction } & 0.0125 \\
\hline & & 0.0250 \\
\hline & & 0.0500 \\
\hline & \multirow{3}{*}{ Infusion } & 0.0125 \\
\hline & & 0.0250 \\
\hline & & 0.0500 \\
\hline & \multirow{3}{*}{ Ultrasound } & 0.0125 \\
\hline & & 0.0250 \\
\hline & & 0.0500 \\
\hline
\end{tabular}




\subsubsection{Mangiferin Quantification}

The mangiferin contents were analyzed via high-performance liquid chromatography (HPLC) using a Shimadzu Prominence Ultra-Fast Liquid Chromatography (UFLC) system consisting of an LC-20AD binary pump (Tokyo, Japan), an SIL-AOAHT auto sampler, a CBM-20A communication system and a CTO-20A column oven. Chromatographic separation was performed using a reversed phase column (Shimadzu, VP-OD5 C18, $150 \times 4.6 \mathrm{~mm}$, i.d. $4 \mu \mathrm{m})$ with a guard column $(10 \times 4.6 \mathrm{~mm})$. The UV diode-array detector (SP-M20A Shimadzu, Japan) recorded from 220 to $380 \mathrm{~nm}$, with detection at $254 \mathrm{~nm}$. The teas were filtered through cellulose membranes (pore size $0.45 \mu \mathrm{m}$ ). A $5 \mu \mathrm{L}$ aliquot was injected into the HPLC system. The mobile phase consisted of $2 \%$ acetic acid in ultrapure water (solvent A) and acetonitrile (solvent B), with the following gradient: $0-20 \mathrm{~min}, 10 \%-20 \%$ (B); 20-23 $\mathrm{min}, 95 \%$ (B); and 23-28 $\mathrm{min}, 10 \%$ (B). The column temperature was $40{ }^{\circ} \mathrm{C}$, and the flow rate was $1.0\left(\mathrm{~mL} \cdot \mathrm{min}^{-1}\right)$. The analytical conditions were based on the procedure used by Ling et al. [26] and Araújo et al. [27]. The mangiferin concentrations were calculated using a mangiferin standard curve generated from pure compounds ( $>95 \%)$, and the results were expressed as milligrams mangiferin per milliliter of tea $\left(\mathrm{mg} \cdot \mathrm{mL}^{-1}\right)$.

\subsubsection{Physical and Chemical Characterization of Tea}

The method that presented the highest concentration of mangiferin was selected to prepare the tea for physical and chemical characterizations, which included analyses of $\mathrm{pH}$ ( $\mathrm{pH}$ meter 966 Plus, BEL), total phenolic content (TP) and antioxidant activity by radical scavenging activity (RSA) as follows.

\section{Total Phenolic (TP) Content}

The phenolic compound content was estimated colorimetrically in the aqueous extract (tea) using the Folin-Ciocalteu reagent [28]. Aliquots of $100 \mu \mathrm{L}$ of tea and $1 \mathrm{~mL}$ of Folin-Ciocalteu reagent $(0.25 \mathrm{~N})$ were mixed and left standing for $3 \mathrm{~min}$. Then, $1 \mathrm{~mL}$ of sodium carbonate $(1 \mathrm{M})$ was added, and the reaction was left for $7 \mathrm{~min}$. Next, $7 \mathrm{~mL}$ of water was added, and the material was stirred for $2 \mathrm{~min}$. The samples were protected from direct exposure to light and allowed to stand for $30 \mathrm{~min}$ at room temperature. The absorbance was measured in a microplate UV/visible spectrophotometer (Term Scientific MultiSkan ${ }^{\mathrm{TM}} \mathrm{GO}$ ) at $726 \mathrm{~nm}$. The results were expressed as milligram equivalents of gallic acid (GAE) per milliliter of sample using a standard curve of gallic acid with concentrations varying from 0.05 to $0.35 \mathrm{mg} \cdot \mathrm{mL}^{-1}$.

\section{Antioxidant Activity (RSA)}

The antioxidant activity was analyzed by the radical scavenging activity method using the 2,2-diphenyl-1-picrilhidrazil-DPPH assay [29]. A $100 \mu \mathrm{L}$ aliquot of the tea was diluted with $900 \mu \mathrm{L}$ of deionized water. Then, $100 \mu \mathrm{L}$ of this solution was mixed with $1.5 \mathrm{~mL}$ of the DPPH solution at $0.1 \mathrm{M}$. The mixture was shaken, homogenized, and kept for $30 \mathrm{~min}$ in the dark. The absorbance was read using a microplate UV/visible spectrophotometer (ELISA; Scientific MultiSkan ${ }^{\mathrm{TM}}$ Term GO) at $517 \mathrm{~nm}$ against a blank ( $100 \mu \mathrm{L}$ of water and $1.5 \mathrm{~mL}$ of $0.1 \mathrm{M}$ solution of DPPH). The data were expressed as the percentage of radical scavenging activity (RSA). The calculation was performed using the following equation:

$$
\% \text { RSA }=\left[\left(\mathrm{A}_{\text {control }}-\mathrm{A}_{\text {sample }}\right) / \mathrm{A}_{\text {control }}\right] \times 100
$$

where $\mathrm{A}$ is the absorbance.

\subsection{Oxidative Stability of the Tea}

The oxidative stability of the tea was evaluated by variation analysis of the phenolic compound content (Folin-Ciocalteu reagent method), the radical scavenging activity (DPPH test) and the 
mangiferin content (HPLC) according to the methodologies described in Sections 2.3.2 and 2.3.3. Two preservation conditions were evaluated (cooling at $4 \pm 2{ }^{\circ} \mathrm{C}$ and room temperature of $20 \pm 2{ }^{\circ} \mathrm{C}$ ) at 0,24 and $48 \mathrm{~h}$ after preparation of the beverage.

\subsection{Sensory Analysis}

\subsubsection{Preparation of the Tea}

Three samples of tea were prepared with the processed leaf of $M$. indica and drinking water at a final M. indica concentration of $5 \%(\mathrm{w} / \mathrm{v})$ using the decoction technique (as described in Section 2.3.1). In two of the samples, artificial flavoring of fennel or orange was added (five drops per $50 \mathrm{~mL}$ to each tea).

\subsubsection{Sensorial Test}

The acceptance of the teas was evaluated by 50 untrained adult panelists of both genders, including university students and officials. Tea samples of $30 \mathrm{~mL}\left(55 \pm 3{ }^{\circ} \mathrm{C}\right)$ were monadically served in white porcelain cups capped with saucers, each receiving a random 3-digit code number along with the evaluation form and one glass of filtered water. A mixed 9-point hedonic scale $(9=$ like extremely; 1 = dislike extremely) was used for aroma, flavor and overall impression [30]. The sensory analysis was conducted in an appropriately designed and lit room and was approved by the Brazilian Ethics Committee under number 845-894/2014.

\subsection{Statistical Analysis}

The design was completely randomized in a $2 \times 3 \times 3$ factorial model (two types of leaves $\times$ three (medicinal plant: solvent) ratios $\times$ three extraction methods). All experiments were performed in triplicate. The data were subjected to analysis of variance (ANOVA) followed by the Tukey test. The results were expressed as the mean \pm standard deviation. The tea stability over time was analyzed by regression. The results of the acceptance test were evaluated by ANOVA using a randomized block design (RBD), followed by the Tukey test. The significance level for all analyses was $5 \%$.

\subsection{Ethical Statements}

All subjects gave their informed consent for inclusion before they participated in the study. The study was conducted in accordance with the Declaration of Helsinki, and the protocol was approved by the Brazilian Ethics Committee under number 845 894/2014.

\section{Results and Discussion}

\subsection{Mangiferin Concentration in Teas}

Overlaid chromatograms obtained from injections of the $M$. indica tea samples for the different treatments are shown in Figure 2. Comparison among the chromatograms indicated that the tea made with $5 \%$ young $M$. indica leaves using the decoction technique presented the highest mangiferin concentration. The same figure showed that mangiferin presented a retention time of approximately $7.75 \mathrm{~min}$, which was compatible with the mangiferin standard.

The mangiferin concentration of the teas was directly proportional to the medicinal plant: solvent ratio, with statistically significant differences among the concentrations (Figure 3). For all three tea preparation techniques, the highest concentration of medicinal plant $(5 \%)$ was the most effective for mangiferin extraction. The mangiferin concentration values found in the teas of $M$. indica leaves prepared by the three techniques, at the three (medicinal plant: solvent) ratios and for the two types of leaves, are presented in Table 2.

Significant differences were observed in the mangiferin concentrations among the tea preparation techniques. The tea prepared by decoction had the highest values of mangiferin $(0.717 \pm 0.08$ and $0.573 \pm 0.01 \mathrm{mg} \cdot \mathrm{mL}^{-1}$ using young and mature leaves, respectively), indicating that the mangiferin extraction by this technique is the most efficient. 
Young leaves
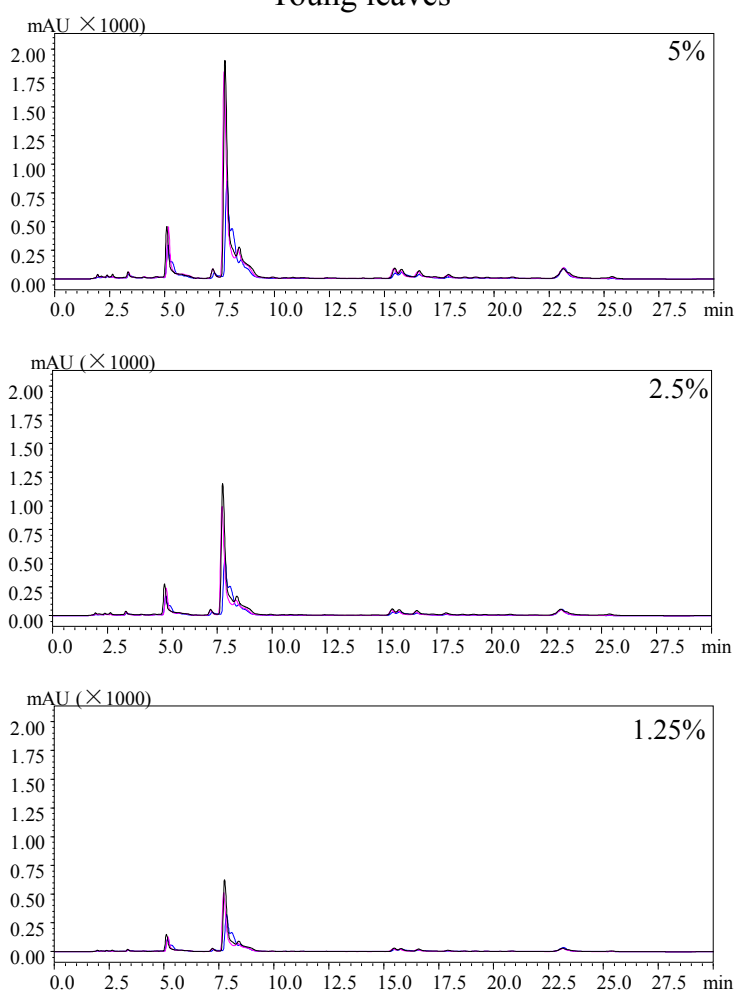

Mature leaves
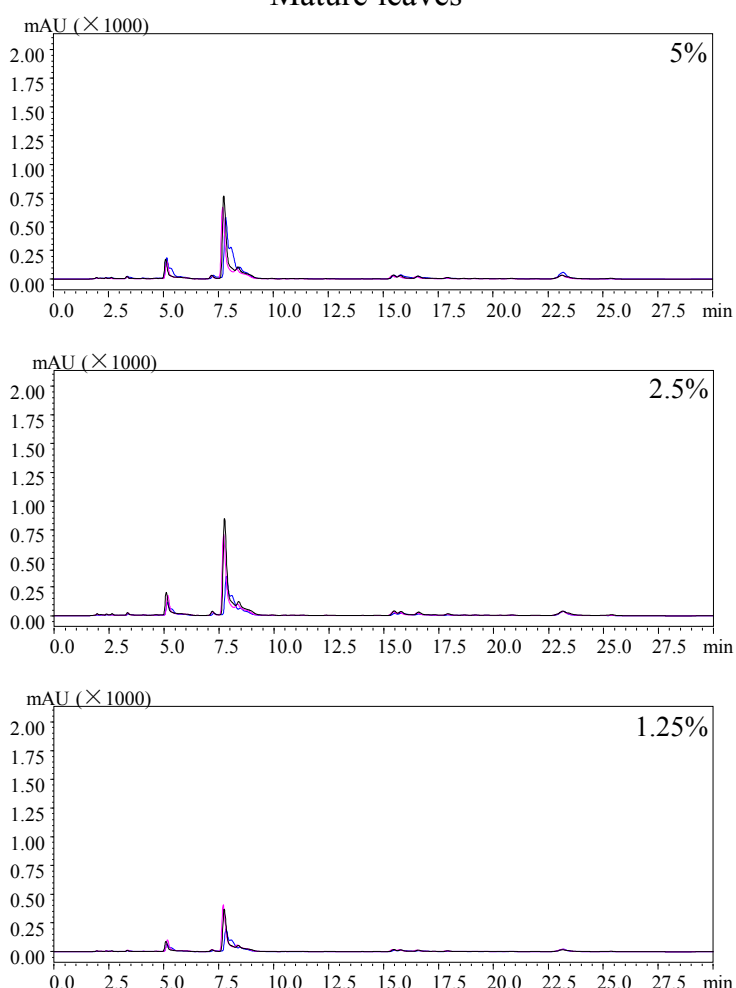

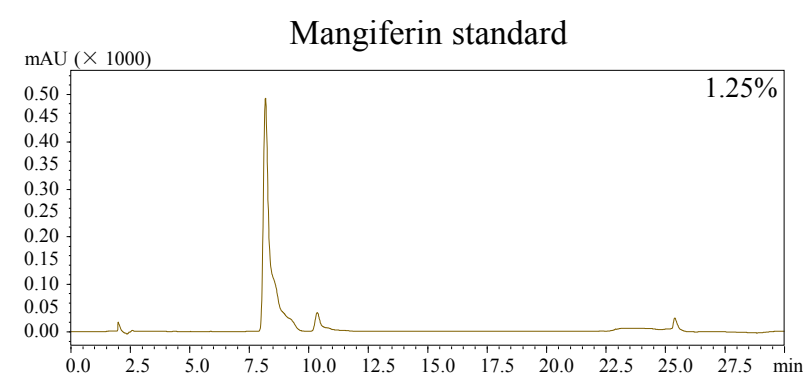

Figure 2. Overlaid HPLC chromatograms of the mangiferin peaks obtained from teas of $M$. indica prepared using young and mature leaves at three different concentrations $(5,2.5$ and $1.25 \mathrm{~g} / 100 \mathrm{~mL})$ through decoction (black peaks), infusion (magenta peaks) and ultrasound (blue peaks) techniques. For the chromatographic conditions, see Section 2.3.2.

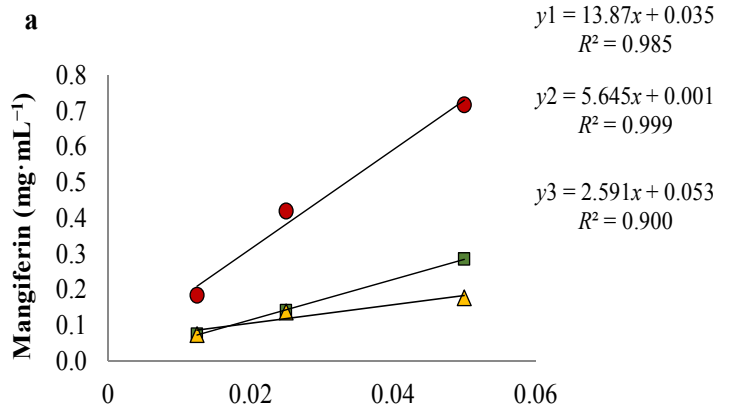

- Decoction (y1) $\square$ Infusion(y2) $\Delta$ Ultrasound (y3)

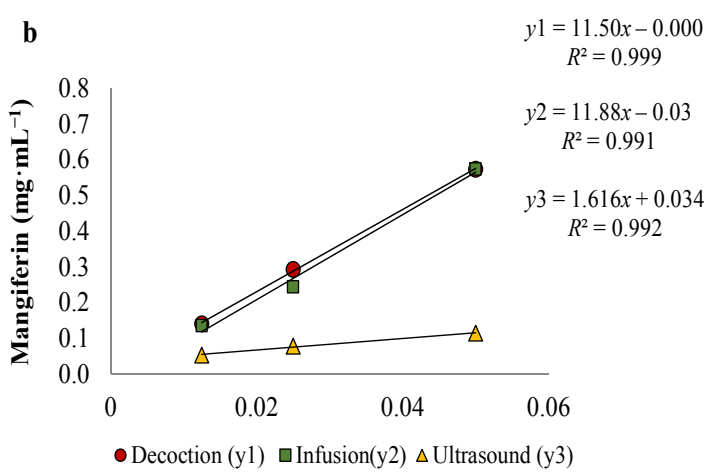

Figure 3. Correlation coefficient and linear regression between the mangiferin content and the medicinal plant: solvent ratio of teas prepared with (a) young; and (b) mature M. indica leaves. 
Table 2. Mangiferin concentration of teas prepared using two types of $M$. indica leaves, three preparation methods and three (medicinal plant: solvent) ratios.

\begin{tabular}{|c|c|c|c|}
\hline \multirow{2}{*}{$\begin{array}{l}\text { Preparation } \\
\text { Technique }\end{array}$} & \multirow{2}{*}{$\begin{array}{l}\text { (Medicinal Plant:Solvent) Ratio } \\
\text { (g of } M . \text { indica Leaves } \cdot \mathrm{mL}^{-1} \text { of water) }\end{array}$} & \multicolumn{2}{|c|}{ Mangiferin $\left(\mathrm{mg} \cdot \mathrm{mL}^{-1}\right)$} \\
\hline & & Young Leaves & Mature Leaves \\
\hline \multirow{3}{*}{ Decoction } & 0.0500 & $0.717 \pm 0.08^{\mathrm{A}}$ & $0.573 \pm 0.01^{\mathrm{B}}$ \\
\hline & 0.0250 & $0.419 \pm 0.04^{a}$ & $0.292 \pm 0.06^{b}$ \\
\hline & 0.0125 & $0.184 \pm 0.01^{I}$ & $0.140 \pm 0.01^{I I}$ \\
\hline \multirow{3}{*}{ Infusion } & 0.0500 & $0.285 \pm 0.01^{\mathrm{C}}$ & $0.572 \pm 0.01^{\mathrm{B}}$ \\
\hline & 0.0250 & $0.140 \pm 0.01^{c}$ & $0.243 \pm 0.02^{b}$ \\
\hline & 0.0125 & $0.074 \pm 0.01^{I I I}$ & $0.135 \pm 0.01^{I I}$ \\
\hline \multirow{3}{*}{ Ultrasound } & 0.0500 & $0.177 \pm 0.02^{\mathrm{D}}$ & $0.114 \pm 0.01^{\mathrm{D}}$ \\
\hline & 0.0250 & $0.137 \pm 0.02^{c}$ & $0.078 \pm 0.01^{\mathrm{c}}$ \\
\hline & 0.0125 & $0.073 \pm 0.01^{I I I}$ & $0.052 \pm 0.01^{I I I}$ \\
\hline
\end{tabular}

Data are expressed as the means \pm s.d. The differences between values are analyzed with ANOVA followed by Tukey's test. ${ }^{A-D} p<0.05$. Concentration of medicinal plant $(5 \%)$ vs. preparation techniques. ${ }^{a-c} p<0.05$. Concentration of medicinal plant $(2.5 \%)$ vs. preparation techniques. ${ }^{I-I I I} p<0.05$. Concentration of medicinal plant $(1.25 \%)$ vs. preparation techniques.

There was a significant difference in the mangiferin concentrations between the types of leaves for all three concentrations and three techniques $(p<0.05)$, and the highest concentration of mangiferin was found in the teas prepared with young leaves by decoction. The use of mature leaves favored mangiferin extraction in the tea prepared by infusion.

Mangiferin extraction by ultrasound was less efficient due to the influence of time and temperature and the saturation of this compound [31]. Chan et al. [32] reported that young leaves of Camellia sinensis had a higher total phenolic content and antioxidant activity than mature leaves, claiming that the young leaves are characterized by the highest amounts of bioactive compounds and nutrients, which are therefore more extractable.

The mangiferin concentration increased proportionately with the amount of medicinal plant in the teas, as expected. This finding corroborates the results of Zaleta et al. [33], who commented that mangiferin presents low solubility in water and that the teas of $M$. indica leaves prepared with the highest (medicinal plant: solvent) ratio have the highest contents of this compound in the preparation.

The decoction method was the most efficient for the extraction of mangiferin, which is important considering that the method is simple and commonly used and therefore accessible by the consumer. In this study, a cup $(240 \mathrm{~mL})$ of $M$. indica leaf tea provides approximately $2.88 \mathrm{mg} \cdot \mathrm{kg}^{-1}$ mangiferin, considering a human adult with a $60 \mathrm{~kg}$ body weight. Studies with rats utilized mangiferin concentrations that varied from 15 to 30 [34], 10 to 30 and 15 to 25 [35] mg. $\mathrm{kg}^{-1}$ of body weight to obtain anti-diabetes, anti-inflammatory and hepatoprotective effects. Converting the dose used in the mentioned experiments in rats to a dose based on surface area for humans (formula for dose translation based on BSA [36]), the values are 2.4 to $4.9,1.6$ to 4.9 and 2.4 to $4.1 \mathrm{mg} \cdot \mathrm{kg}^{-1}$ respectively, for a $60 \mathrm{~kg}$ person. The mangiferin contained in a portion of $M$. indica leaf tea is within these ranges, suggesting that this tea has potential as a functional beverage. Additionally, there are other bioactive compounds in the human diet that can exert synergistic biologic activity with the phytochemicals contained in M. indica leaf tea, increasing the beneficial health effects.

With respect to toxicity, a study with rats showed that the level of mangiferin required to trigger myocardial infarction is above $1000 \mathrm{mg} \cdot \mathrm{kg}^{-1}$ per day [37]. In this study, the mangiferin levels are low, indicating that the tea could be consumed without producing toxic effects. 


\subsection{Physicochemical Characterization of the Tea}

Taking into account that decoction was the optimal method for mangiferin extraction, a tea was prepared with young $M$. indica leaves at $5 \%$ concentration using this technique for physicochemical characterization. The results are presented in Table 3. The $\mathrm{pH}$ value of the $M$. indica leaf tea was similar to the result described for green tea $(\mathrm{pH}=5.3)$. Commercial plant-based teas are slightly acidic, with $\mathrm{pH}$ values ranging from 4.0 to 6.0 [38]. Tannins are found in foods and beverages, especially in green and black tea. They confer acidity and astringency to wine and a variety of drinks [39,40]. Although the tannin content was not determined in this study, M. indica has been reported to contain gallotannins [41], suggesting that teas made from its leaves contain certain amounts of these compounds, which may be related to the acidity, astringency and bitterness of these beverages.

Regarding the total phenolic content, the evaluated tea contains high amounts of this phytochemical group and is capable of providing approximately $381 \mathrm{mg}$ of phenolic compounds, expressed as GAE, in $240 \mathrm{~mL}$. Considering that the average human ingestion of phenolic compounds is $1123 \mathrm{mg}$ per day [42], tea consumption can enhance the intake of this phytochemical group by approximately $30 \%$, increasing the antioxidant capacity in the diet. The antioxidant activity of tea, evaluated by radical scavenging activity, was $80 \%$, indicating that the $\mathrm{EC}_{50}$ value is less than $0.007 \mu \mathrm{g} \cdot \mu \mathrm{L}^{-1}$. $\mathrm{EC}_{50}$ represents the antioxidant concentration that inhibits $50 \%$ of the oxidation reaction under the assay conditions.

Some authors have reported that herb infusions have potential applications as sources of total phenolic and antioxidant activity. However, it is inadequate to compare the phenolic contents and antioxidant activity observed in this work with the results obtained in other studies, especially as there have been a limited number of tests performed with $M$. indica leaves under different preparation techniques and assay conditions $[43,44]$.

The scientific literature contains reports of the beneficial effects of bioactive compounds in teas on the reduction of chronic disease risk. A study demonstrated the suppressing effect of Goishi and green tea at $5 \%(\mathrm{w} / \mathrm{v})$ on the adipose cell growth of obesity-induced rats [45]. Total phenolics are potential agents in the prevention of obesity and diabetes [46]. Favorable anti-obesity effects [47] and improvement of cardiovascular disease [48] have been attributed to the total phenolics present in green and black tea extracts. The low intake of bioactive compounds is a risk factor for chronic, non-communicable diseases [49].

Table 3. Mean values of the $\mathrm{pH}$, total phenolic content and antioxidant activity of $M$. indica leaf tea at a $5 \%$ (medicinal plant: solvent) ratio.

\begin{tabular}{cc}
\hline Parameter & Values \\
\hline $\mathrm{pH}$ & $5.140 \pm 0.04$ \\
Total phenolic $\left(\mathrm{mg} \mathrm{GAE} \cdot \mathrm{mL}^{-1}\right)$ & $1.595 \pm 0.11$ \\
Antioxidant activity * $(\mathrm{RSA} \%)$ & $80.331 \pm 0.18$ \\
\hline \multicolumn{2}{c}{ * Analyzed by DPPH test. }
\end{tabular}

\subsection{Stability}

There was no significant variation in the mangiferin concentration and total phenolic content up to $48 \mathrm{~h}$ after the preparation of the teas (Figure $4 \mathrm{a}, \mathrm{b}$ ).

Even though there was a negative variation in the antioxidant activity (\% RSA) of the teas under both preservation methods at $24 \mathrm{~h}$, the activity was stable at $48 \mathrm{~h}$, exhibiting a value statistically equal to the one found at the initial time (Figure 4c). This variation is observed in processed vegetable raw materials and can be attributed to the influence of the phenolic compound levels $[43,50]$, to the preparation method of teas [51,52], or to interactions associated with other compounds present in $M$. indica leaf tea, which were not evaluated in this study. 

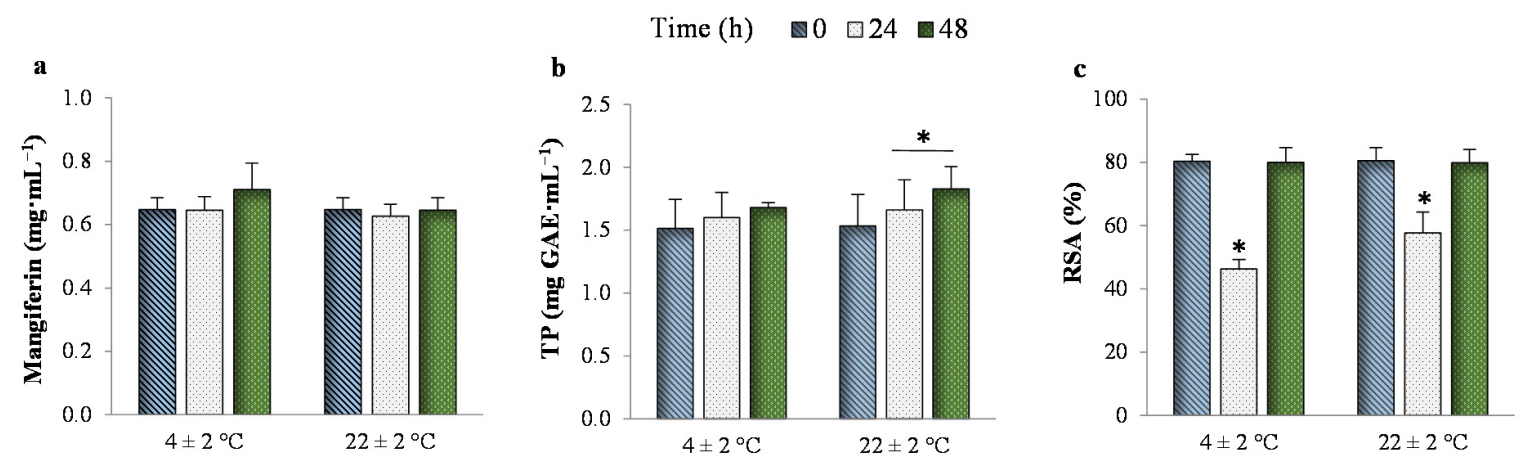

Figure 4. Stability of the contents of (a) mangiferin; and (b) total phenolics; and of the (c) radical scavenging activity of teas for both preservation methods (cooling $4 \pm 2{ }^{\circ} \mathrm{C}$ and room temperature $\left.20 \pm 2{ }^{\circ} \mathrm{C}\right)$ at different times $(0,24$ and $48 \mathrm{~h}) .{ }^{*} p<0.05$. Significant differences between times for the same temperatures (analysis of variance followed by the Tukey test).

A stability analysis of fermented soy milk-added teas (green and black) reported variations in the content of phenolic compounds and antioxidants influenced by the storage time at $4{ }^{\circ} \mathrm{C}$ [53]. In this study, the tea was stable for up to $48 \mathrm{~h}$ after preparation. The oxidative stability of these functional compounds in the tea suggests that the functional properties were preserved during the evaluation period. In industrial terms, this result is a positive factor for the development of new beverages that could be commercialized as sources of phytochemicals.

Microbiological analysis and sensory stability were also performed. For the preparation of tea, at the household level, stability ensures convenience to the consumer. This study suggests that during the first $48 \mathrm{~h}, \mathrm{M}$. indica leaf tea does not require refrigeration to preserve its mangiferin content and its antioxidant activity. These results corroborate the results from Rubio-Perez et al. [54], who showed that the antioxidant compounds of green tea blended with apple are stable at room temperature and do not require refrigeration.

\subsection{Sensory Analysis}

The results of the sensory evaluations of aroma, flavor and overall impression showed differences between the natural teas and the flavored teas. The mean overall impression of the natural teas $(5.7 \pm 1.9)$ was similar to the results reported for ginseng tea with sugar added [55]. Sugar or sweeteners can influence the consumer preference for foods and beverages [56]. In terms of health, high sugar consumption has been associated with increased risk of developing chronic diseases $[57,58]$. The teas from $M$. indica leaves did not include any additional sugar-sweeteners.

The flavor scores for teas from $M$. indica leaves were similar to the scores for canned green tea [59]. The scores for overall acceptability were considerably higher than those in mate and green tea studies $[60,61]$. Mango is accepted by the consumers due to its delicious taste, flavor and aroma. This fruit contains several volatile compounds that contribute to the aroma, which is so strong that it can influence the flavor perception $[62,63]$, which may explain the higher scores for natural M. indica leaf tea. The teas with flavors added presented higher levels of acceptance $(p<0.05)$ in all evaluated attributes, indicating the positive effect of adding flavoring agents to $M$. indica leaf tea (Table 4). On the other hand, the tea without flavor added fell essentially in the 'neither like nor dislike' range. Sensory quality is regarded as a marketing and production strategy when it influences food quality and is a key to food perception acceptance by the consumer $[60,64]$. The addition of flavoring agents does not alter the nutritional properties of foods and can improve consumer perception, helping to improve acceptance. There is evidence that when taste and odor are encoded together as flavor, they interact to modify perception [65]. This study showed that $M$. indica leaf tea was well accepted by the consumers, and this acceptance was due to the addition of a flavoring agent. This finding 
suggests that the development of an $M$. indica leaf beverage through the addition of an appropriate flavor for sensory improvement is promising. However, these consumer results should be considered preliminary because of the small sample size and the nature of the consumer sample (only students and university officials were used). Further research will need to be conducted to confirm these results.

Table 4. Average values of the scores obtained by the sensory analysis of $M$. indica leaf tea.

\begin{tabular}{cccc}
\hline \multirow{2}{*}{ Teas } & \multicolumn{3}{c}{ Attribute } \\
\cline { 2 - 4 } & Aroma & Flavor & Overall Impression \\
\hline Natural $^{*} 6.5 \pm 1.8^{\mathrm{b}}$ & $5.3 \pm 2.1^{\mathrm{b}}$ & $5.7 \pm 1.9^{\mathrm{b}}$ \\
Orange $^{*}$ & $7.7 \pm 1.3^{\mathrm{a}}$ & $6.2 \pm 1.7^{\mathrm{a}}$ & $6.5 \pm 1.6^{\mathrm{a}}$ \\
Fennel $^{*}$ & $7.7 \pm 1.1^{\mathrm{a}}$ & $6.3 \pm 2.3^{\mathrm{a}}$ & $6.7 \pm 1.7^{\mathrm{a}}$ \\
\hline
\end{tabular}

Data are expressed as means \pm s.d. ${ }^{\mathrm{a}-\mathrm{c}} p<0.05$. Significant differences between tastes for the same attribute (analysis of variance followed by the Tukey test). Evaluated with a mixed, 9 -point hedonic scale $(9=$ like extremely; 1 = dislike extremely). $N=50 .{ }^{*}$ Teas with the addition of orange or fennel flavors.

\section{Conclusions}

This study showed the development of $M$. indica leaf tea as well as its chemical characterization, stability and sensory acceptance. Our results indicated that $M$. indica leaf tea can be consumed as a source of bioactive compounds, mainly mangiferin. This tea presented $80 \%$ radical scavenging activity, suggesting its potential as an antioxidant beverage. The intake of $M$. indica leaf tea is a strategy to supply phytochemicals to the human diet that offers an opportunity to develop a new functional beverage. Further studies on the toxicological and biological effects of $M$. indica leaf tea are required to guarantee the safety of this beverage.

Acknowledgments: The authors are thankful for the financial support provided by "Fundação de Amparo à Pesquisa do Estado de Minas Gerais" (FAPEMIG-Number 34/2013), the "Coordenação de Aperfeiçoamento de Pessoal de Nível Superior" (CAPES) foundation and the National Counsel of Technological and Scientific Development (CNPQ).

Author Contributions: We confirm that the version published has been read and approved, for all named authors. As co-authors, we have participated substantially in this study to take public responsibility for integrity of the work. All authors contributed reagents/materials/analysis tools/designed of experiments and acquisition of data. Natalia M. Ramírez and Sônia M. R. Ribeiro also performed the experiments and wrote the manuscript. Maria I. S. Dantas, Hercia S. D. Martino and Sônia M. R. Ribeiro conceived the project.

Conflicts of Interest: The authors declare no conflict of interest.

\section{References}

1. Han, C. Studies on tea and health. J. Hyg. Res. 2011, 40, 802-805.

2. Khan, N.; Mukhtar, H. Tea and health: Studies in humans. Curr. Pharm. Des. 2013, 19, 6141-6147. [CrossRef] [PubMed]

3. Jin, L.; Li, X.-B.; Tian, D.-Q.; Fang, X.-P.; Yu, Y.-M.; Zhu, H.-Q.; Ge, Y.-Y.; Ma, G.-Y.; Wang, W.-Y.; Xiao, W.-F.; et al. Antioxidant properties and color parameters of herbal teas in china. Ind. Crops Prod. 2016, 87, 198-209. [CrossRef]

4. Unno, K.; Hara, A.; Nakagawa, A.; Iguchi, K.; Ohshio, M.; Morita, A.; Nakamura, Y. Anti-stress effects of drinking green tea with lowered caffeine and enriched theanine, epigallocatechin and arginine on psychosocial stress induced adrenal hypertrophy in mice. Phytomedicine 2016, 23, 1365-1374. [CrossRef] [PubMed]

5. $\quad$ Li, F.-D.; He, F.; Ye, X.-J.; Shen, W.; Wu, Y.-P.; Zhai, Y.-J.; Wang, X.-Y.; Lin, J.-F. Tea consumption is inversely associated with depressive symptoms in the elderly: A cross-sectional study in eastern china. J. Affect. Disord. 2016, 199, 157-162. [CrossRef] [PubMed]

6. Wauthoz, N.; Balde, A.; Balde, E.S.; Damme, M.V.; Duez, P. Ethnopharmacology of Mangifera indica L. Bark and pharmacological studies of its main c glucosylxanthone, mangiferin. Int. J. Biomed. Pharm. Sci. 2007, 1, 112-119. 
7. Saleh, I.G.; Ali, Z.; Abe, N.; Wilson, F.D.; Hamada, F.M.; Abd-Ellah, M.F.; Walker, L.; Khan, I.A.; Ashfaq, M.K. Effect of green tea and its polyphenols on mouse liver. Fitoterapia 2013, 90, 151-159. [CrossRef] [PubMed]

8. Journal Valor Economico Consumo de Chá Aumenta e se Sofistica No Brasil. Available online: http: //www.valor.com.br/empresas/2737452/consumo-de-cha-aumenta-e-se-sofistica-no-brasil (accessed on 16 July 2014).

9. Moriyama, H.; Takeda, N. Catechin contents in microbial fermented tea, goichi tea. Rep. Kochi Prefect. Ind. Technol. Center 2008, 39, 7-9.

10. Ferreira, D.F. Sisvar: A computer statistical analysis system. Ciênc. Agrotec. 2011, 35, 1039-1042.

11. Da Silva, J.K.; Batista, Â.G.; Cazarin, C.B.B.; Dionísio, A.P.; de Brito, E.S.; Marques, A.T.B.; Maróstica Junior, M.R. Functional tea from a brazilian berry: Overview of the bioactives compounds. LWT Food Sci. Technol. 2016. [CrossRef]

12. Ponce, M.T.F.; Casas, L.; Mantell, C.; Rodríguez, M.; Martínez de la Ossa, E. Extraction of antioxidant compounds from different varieties of Mangifera indica leaves using green technologies. J. Supercrit. Fluids 2012, 72, 168-175. [CrossRef]

13. Rodeiro, I.; Donato, M.T.; Jiménez, N.; Garrido, G.; Delgado, R.; Lechón, M.J.G. Effects of Mangifera indica L. Aqueous extract (vimang) on primary culture of rat hepatocytes. Food Chem. Toxicol. 2007, 45, 2506-2512. [CrossRef] [PubMed]

14. Matkowski, A.; Kuś, P.; Góralska, E.; Woźniak, D. Mangiferin-A bioactive xanthonoid, not only from mango and not just antioxidant. Mini Rev. Med. Chem. 2013, 13, 439-455. [CrossRef] [PubMed]

15. Valle, L.G.D.; Serrano, T.; Calderón, O.; Núñez, F.; Tápanes, R.D.; Pérez, J. Effect of vimang in HIV / AIDS patients. Revis. Cuba. Med. Trop. 2010, 62, 200-206.

16. Milenkovic, D.; Jude, B.; Morand, C. Mirna as molecular target of polyphenols underlying their biological effects. Free Radic. Biol. Med. 2013, 64, 40-51. [CrossRef] [PubMed]

17. Donath, M.Y. Targeting inflammation in the treatment of type 2 diabetes: Time to start. Nat. Rev. Drug Discov. 2014, 13, 465-476. [CrossRef] [PubMed]

18. Resolução da Diretoria Colegiada-RDC $N^{\circ}$ 26; Ministério da Saúde, Agência Nacional de Vigilância Sanitária (ANVISA): Brasilia, Brasil, 2014.

19. Vidigal, M.; Minim, V.; Carvalho, N.; Milagres, M.; Gonçalves, A. Effect of a health claim on consumer acceptance of exotic brazilian fruit juices: Açaí (Euterpe oleracea Mart.), Camu-camu (Myrciaria dubia), Cajá (Spondias lutea L.) and Umbu (Spondias tuberosa Arruda). Food Res. Int. 2011, 44, 1988-1996. [CrossRef]

20. Pineli, L.D.; Rodrigues, J.D.; Costa, A.M.; de Lima, H.C.; Chiarello, M.D.; Melo, L. Antioxidants and sensory properties of the infusions of wild passiflora from brazilian savannah: Potential as functional beverages. J. Sci. Food Agric. 2015, 95, 1500-1506. [CrossRef] [PubMed]

21. De Bouillé, A.G.; Beeren, C.J.M. 7-Sensory evaluation methods for food and beverage shelf life assessment. In The Stability and Shelf Life of Food, 2nd ed.; Subramaniam, D.K.A.P., Ed.; Woodhead Publishing Limited: Cambridge, UK, 2016; pp. 199-228.

22. Ibrahim, F.Y.; El-Khateeb, A.Y. Effect of herbal beverages of foeniculum vulgare and cymbopogon proximus on inhibition of calcium oxalate renal crystals formation in rats. Ann. Agric. Sci. 2013, 58, 221-229. [CrossRef]

23. Zheng, W.; Wang, S.Y. Antioxidant activity and phenolic compounds in selected herbs. J. Agric. Food Chem. 2001, 49, 5165-5170. [CrossRef] [PubMed]

24. Katalinic, V.; Milos, M.; Kulisic, T.; Jukic, M. Screening of 70 medicinal plant extracts for antioxidant capacity and total phenols. Food Chem. 2006, 94, 550-557. [CrossRef]

25. Costa, A.S.G.; Nunes, M.A.; Almeida, I.M.C.; Carvalho, M.R.; Barroso, M.F.; Alves, R.C.; Oliveira, M.B.P.P. Teas, dietary supplements and fruit juices: A comparative study regarding antioxidant activity and bioactive compounds. LWT Food Sci. Technol. 2012, 49, 324-328. [CrossRef]

26. Ling, L.T.; Yap, S.-A.; Radhakrishnan, A.K.; Subramaniam, T.; Cheng, H.M.; Palanisamy, U.D. Standardised mangifera indica extract is an ideal antioxidant. Food Chem. 2009, 113, 1154-1159. [CrossRef]

27. Araújo, B.M.; Gonçalves, R.V.; Peluzio, M.D.; Leite, J.P.; dos Santos Chaves, G.; Lopes, S.O.; do Carmo Miranda, C.; de Queiroz, J.H. Use of Mangifera indica L. Leaves extract and mangiferin on the atherosclerotic lesion in ApoE ${ }^{-/-}$mice. Biosci. J. 2014, 30, 1873-1881.

28. Folin, O.; Ciocalteu, V. On tyrosine and tryptophane determinations in proteins. J. Biol. Chem. 1927, 73, $627-650$. 
29. Blois, M.S. Antioxidant determinations by the use of a stable free radical. Nature 1958, 181, 1199-1200. [CrossRef]

30. Stone, H.; Sidel, J.L. Sensory Evaluation Practices; Food Science and Technology; Academic Press: New York, NY, USA, 1993; Volume 2, p. 338.

31. Kulkarni, V.M.; Rathod, V.K. Extraction of mangiferin from Mangifera indica leaves using threephase partitioning coupled with ultrasound. Ind. Crops Prod. 2014, 52, 292-297. [CrossRef]

32. Chan, E.W.C.; Lim, Y.Y.; Chew, Y.L. Antioxidant activity of Camellia sinensis leaves and tea from a lowland plantation in Malaysia. Food Chem. 2007, 102, 1214-1222. [CrossRef]

33. Zaleta, B.; Silva, M.T.; Gutiérrez, A.; Vergara, E.; Rodríguez, M.; Hernández, A. UV/Vis, ${ }^{1}$ H, and ${ }^{1} 3 C$ NMR spectroscopic studies to determine mangiferin pKa values. Spectrochim. Acta Part A Mol. Biomol. Spectrosc. 2006, 64, 1002-1009. [CrossRef] [PubMed]

34. Gao, D.; Jin, F.; Liu, H.; Wang, Y.; Jiang, Y. Metabonomic study on the antitumor effect of flavonoid derivative 3d in HepG2 cells and its action mechanism. Talanta 2014, 118, 382-388. [CrossRef] [PubMed]

35. Gong, X.; Zhang, L.; Jiang, R.; Ye, M.; Yin, X.; Wan, J. Anti-inflammatory effects of mangiferin on sepsis-induced lung injury in mice via up-regulation of heme oxygenase-1. J. Nutr. Biochem. 2013, 24, 1173-1181. [CrossRef] [PubMed]

36. Reagan-Shaw, S.; Nihal, M.; Ahmad, N. Dose translation from animal to human studies revisited. FASEB J. 2008, 22, 659-661. [CrossRef] [PubMed]

37. Prabhu, S.; Jainu, M.; Sabitha, K.E.; Devi, C.S.S. Role of mangiferin on biochemical alterations and antioxidant status in isoproterenol-induced myocardial infarction in rats. J. Ethnopharmacol. 2006, 107, 126-133. [CrossRef] [PubMed]

38. Vuong, Q.V.; Golding, J.B.; Stathopoulos, C.E.; Roach, P.D. Effects of aqueous brewing solution ph on the extraction of the major green tea constituents. Food Res. Int. 2013, 53, 713-719. [CrossRef]

39. Cabrera, C.; Artacho, R.; Gimenez, R. Beneficial effects of green tea-A review. J. Am. Coll. Nutr. 2006, 25, 79-99. [CrossRef] [PubMed]

40. Lima, M.B.; Andrade, S.I.E.; Harding, D.P.; Pistonesi, M.F.; Band, B.S.F.; Araújo, M.C.U. Turbidimetric and photometric determination of total tannins in tea using a micro-flow-batch analyzer. Talanta 2012, 88, 717-723. [CrossRef] [PubMed]

41. Luo, F.; Fu, Y.; Xiang, Y.; Yan, S.; Hu, G.; Huang, X.; Huang, G.; Sun, C.; Li, X.; Chen, K. Identification and quantification of gallotannins in mango (Mangifera indica L.) kernel and peel and their antiproliferative activities. J. Funct. Foods 2014, 8, 282-291. [CrossRef]

42. Jiménez, J.P.; Fezeu, L.; Touvier, M.; Arnault, N.; Manach, C.; Hercberg, S.; Galan, P.; Scalbert, A. Dietary intake of 337 polyphenols in french adults. Am. J. Clin. Nutr. 2011, 93, 1220-1228. [CrossRef] [PubMed]

43. Caia, Y.; Luob, Q.; Sunc, M.; Corke, H. Antioxidant activity and phenolic compounds of 112 traditional chinese medicinal plants associated with anticancer. Life Sci. 2004, 74, 2157-2184. [CrossRef] [PubMed]

44. Port's, P.D.S.; Chisté, R.C.; Godoy, H.T.; Prado, M.A. The phenolic compounds and the antioxidant potential of infusion of herbs from the brazilian amazonian region. Food Res. Int. 2013, 53, 875-881.

45. Jobu, K.; Yokota, J.; Yoshioka, S.; Moriyama, H.; Murata, S.; Ohishi, M.; Ukeda, H.; Miyamura, M. Effects of goishi tea on diet-induced obesity in mice. Food Res. Int. 2013, 54, 324-329. [CrossRef]

46. Snoussi, C.; Ducroc, R.; Hamdaoui, M.H.; Dhaouadi, K.; Abaidi, H.; Cluzeaud, F.; Nazaret, C.; Le Gall, M.; Bado, A. Green tea decoction improves glucose tolerance and reduces weight gain of rats fed normal and high-fat diet. J. Nutr. Biochem. 2014, 25, 557-564. [CrossRef] [PubMed]

47. Uchiyama, S.; Taniguchi, Y.; Saka, A.; Yoshida, A.; Yajima, H. Prevention of diet-induced obesity by dietary black tea polyphenols extract in vitro and in vivo. Nutrition 2011, 27, 287-292. [CrossRef] [PubMed]

48. Bahorun, T.; Luximon-Ramma, A.; Neergheen-Bhujun, V.S.; Gunness, T.K.; Googoolye, K.; Auger, C.; Crozier, A.; Aruom, O.I. The effect of black tea on risk factors of cardiovascular disease in a normal population. Prev. Med. 2012, 54, S98-S102. [CrossRef] [PubMed]

49. Holst, B.; Williamson, G. Nutrients and phytochemicals: From bioavailability to bioefficacy beyond antioxidants. Curr. Opin. Biotechnol. 2008, 19, 73-82. [CrossRef] [PubMed]

50. Wong, S.P.; Leong, L.P.; Koh, J.H.W. Antioxidant activities of aqueous extracts of selected plants. Food Chem. 2006, 99, 775-783. [CrossRef]

51. Prior, R.L.; Cao, G. Antioxidant capacity and polyphenolic components of teas: Implications for altering in vivo antioxidant status. Proc. Soc. Exp. Biol. Med. 1999, 220, 255-261. [CrossRef] [PubMed] 
52. Bassani, D.C.; Nunes, D.S.; Granato, D. Optimization of phenolics and flavonoids extraction conditions and antioxidant activity of roasted Yerba-Mate leaves (Ilex paraguariensis A. St.-Hil., Aquifoliaceae) using response surface methodology. An. Acad. Bras. Ciênc. 2014, 86, 923-933. [CrossRef]

53. Zhao, D.; Shah, N.P. Antiradical and tea polyphenol-stabilizing ability of functional fermented soymilk-tea beverage. Food Chem. 2014, 158, 262-269. [CrossRef] [PubMed]

54. Rubio-Perez, J.M.; Vidal-Guevara, M.L.; Zafrilla, P.; Morillas-Ruiz, J.M. A new antioxidant beverage produced with green tea and apple. Int. J. Food Sci. Nutr. 2014, 65, 552-557. [CrossRef] [PubMed]

55. Chung, H.S.; Lee, Y.-C.; Kyung Rhee, Y.; Lee, S.-Y. Consumer acceptance of ginseng food products. J. Food Sci. 2011, 76, S516-S522. [CrossRef] [PubMed]

56. Keast, R.S.J. Effects of sugar and fat consumption on sweet and fat taste. Curr. Opin. Behav. Sci. 2016, 9, 55-60. [CrossRef]

57. Bray, G.A.; Popkin, B.M. Dietary sugar and body weight: Have we reached a crisis in the epidemic of obesity and diabetes?: Health be damned! Pour on the sugar. Diabetes Care 2014, 37, 950-956. [CrossRef] [PubMed]

58. Siervo, M.; Montagnese, C.; Mathers, J.C.; Soroka, K.R.; Stephan, B.C.; Wells, J.C. Sugar consumption and global prevalence of obesity and hypertension: An ecological analysis. Public Health Nutr. 2014, 17, 587-596. [CrossRef] [PubMed]

59. Cho, H.-Y.; Chung, S.-J.; Kim, H.-S.; Kim, K.-O.K. Effect of sensory characteristics and non-sensory factors on consumer liking of various canned tea products. J. Food Sci. 2005, 70, S532-S538. [CrossRef]

60. De Godoy, R.C.; Deliza, R.; Gheno, L.B.; Licodiedoff, S.; Frizon, C.N.; Ribani, R.H.; dos Santos, G.G. Consumer perceptions, attitudes and acceptance of new and traditional mate tea products. Food Res. Int. 2013, 53, 801-807. [CrossRef]

61. Lee, J.; CHAMBERS IV, E.; Chambers, D.; Chun, S.; Oupadissakoon, C.; Johnson, D. Consumer acceptance for green tea by consumers in the united states, korea and thailand. J. Sens. Stud. 2010, 25, 109-132. [CrossRef]

62. Andrade, E.H.A.; Maia, J.G.S.; Maria das Graças, B.Z. Aroma volatile constituents of brazilian varieties of mango fruit. J. Food Compos. Anal. 2000, 13, 27-33. [CrossRef]

63. Musharraf, S.G.; Uddin, J.; Siddiqui, A.J.; Akram, M.I. Quantification of aroma constituents of mango sap from different pakistan mango cultivars using gas chromatography triple quadrupole mass spectrometry. Food Chem. 2016, 196, 1355-1360. [CrossRef] [PubMed]

64. Sook Chung, H.; Lee, S.Y. Modification of ginseng flavors by bitter compounds found in chocolate and coffee. J. Food Sci. 2012, 77, S202-S210. [CrossRef] [PubMed]

65. Prescott, J. Chemosensory learning and flavour: Perception, preference and intake. Physiol. Behav. 2012, 107, 553-559. [CrossRef] [PubMed]

(C) 2016 by the authors; licensee MDPI, Basel, Switzerland. This article is an open access article distributed under the terms and conditions of the Creative Commons Attribution (CC-BY) license (http://creativecommons.org/licenses/by/4.0/). 